\title{
上顥に生した巨大な周辺性化骨性線維腫について
}

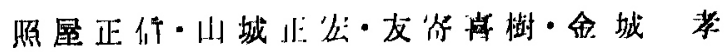

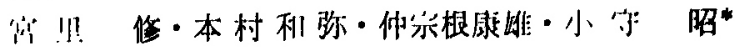

\section{Peripheral ossifying fibroma of the maxilla}

\author{
Masanobu Teruya - Masahiro Yamasinro - Yoshitalsu Tomoyosi: - Takashi Kinjo
}

Osamu Miyazato - Kazuya Motomura - Ýasuo Nakasone - Akira Komori*

緒

言

われわれは上顠に生し，口腔の大部分を占めた巨大な 周辺性化骨性線維腫の 1 例を維験したので，その概要を 報告する。

症

例

患 者:27歳 女性.

初 診: 昭和55年 3 月日日.

主 訴: 右側上䫑部の腫瘤.

家族歴：特記事項なし。

既往歴: 10 年前に甲状腺機能六進症て乎術を受けた が，現在異常はない，5年前に子宮筋腫および十二指腸 溃場と診断されたが特に加療していない、

現病歴：患者は初診の 1 年前. 右側上䪽臼部残根上 の腫瘤に気付き，某菌科を受診したところ，切除をすす められたが放置していた。しかし腫瘤が次第に增大し， 発音障害和よび咀賠障害をきたしたので，当科を紹介さ れ来院した。

現 症: 全身所見; 身長は $153 \mathrm{~cm}$ ，体重は $38 \mathrm{~kg}$ で 栄羡不良であった，眼瞼結膜に貧血が認められた，顔貌 は左右非対称で，右側頓部にびまん性腫涱がみられた (写直 1).

口腔内所見；右上䫑に右側煩部から口蓋にかけて，

琉球大学医学部附属病院菌科口腔外科

（主任：山城正宏教授）

* 徳岛大学梅学部口腔病理学䔳座

（主任：小守 昭教授）

Department of Oral Surgery, School of Medicine, University of the Ryukyus (Chief: Prof. Masahiro Yamasiro)

* Department of Oral Pathology, School of Dentistry, Tokushima University (Chief: Prof. Akira Komori)

受付日 : 昭和 57 年 12 月 27 日

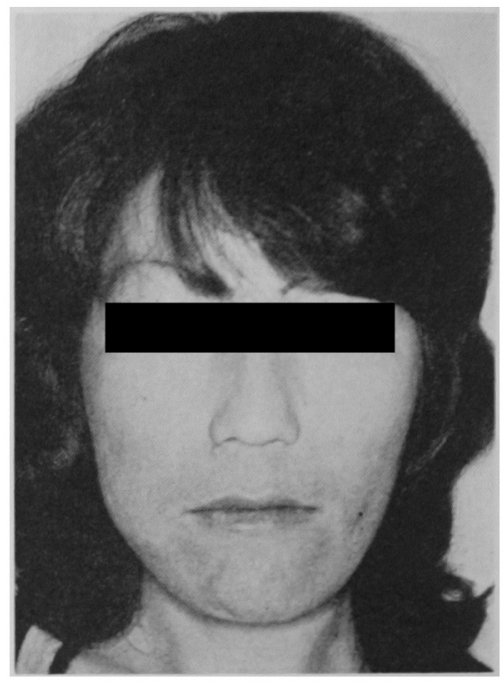

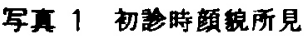

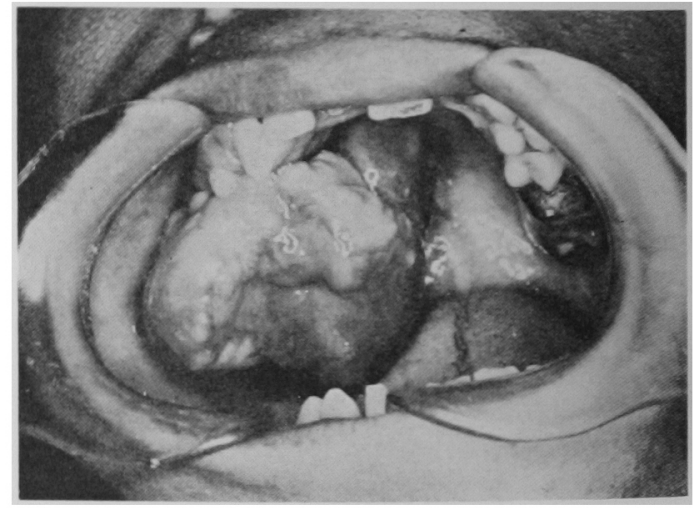

写更 2 初祅時口佂内所見

$4.1 \times 4.0 \times 3.5 \mathrm{~cm}$ 大の腫瘤が 突出し, 表面は帯赤色で 凹凸不整を呈していた，右下影歯槽堤に対応して，鞍状 の圧痕が認められた。腫瘤は弾性硬および可動性を示 し，压痛は認められなかった（写真2），初診より3か 
变 1

\begin{tabular}{|c|c|c|c|c|c|c|}
\hline 報 告 者 & $\begin{array}{c}\text { 大杰ら } \\
(1954)\end{array}$ & ${ }_{(1978)}^{\text {伊 }}$ & $\begin{array}{l}\text { 相 } 5 \\
(1979)\end{array}$ & \multicolumn{2}{|c|}{ 仙 聺 $^{5}$} & 萻者 ら \\
\hline 性・年跑 & 우 19 & 우· 56 & 우· 52 & 우 - 48 & 우· 59 & 우· 27 \\
\hline 研 & 崖度自発痛 & 踷 煌 & 陫济 & & 膘胜 & 胉 留 \\
\hline $\begin{array}{l}\text { 自覚時期より } \\
\text { 初診まで期间 }\end{array}$ & 5 か & 4 年 & 3 年 & 2 Al: & 6 只 & 1 年 \\
\hline 自党 症 状 & 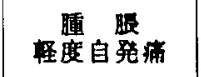 & 速初 & 谐溜 & 胉限 & 嘎腿 & 近筑 \\
\hline 発 現 部 位 & 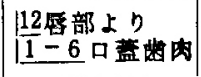 & 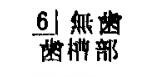 & 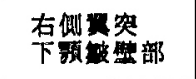 & 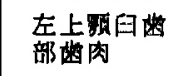 & $\overline{1}^{1-3}$ 部 & 右侧上硕 \\
\hline 基部の有 無 & 有 & 有 & 無 & 有 & 有 & 有 \\
\hline $\mathrm{X}$ 線 所 見 & 要骨様の你 & 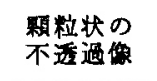 & $\begin{array}{l}\text { 数個の } \\
\text { 不透過像 }\end{array}$ & 異常なし & 異常なし & $\begin{array}{l}\text { 不规則顆粒状 } \\
\text { の不这遇物 }\end{array}$ \\
\hline 嚂床橹查所見 & 正 常 & 正 常 & 正 常 & 正 常 & 正 常 & $\mathrm{HB}$ 抗原 $(+)$ \\
\hline 隕 床 診 & 不 明 & 不 明 & $\begin{array}{l}\text { 骨形成性 } \\
\text { 線䊒膇 }\end{array}$ & エプーリス & エブーリス & 上额腫的 \\
\hline 置 & 摘出 - 搔彴 & 摘出 - 掅爬 & 墒 出 & 摘 出 & 推出 & 摘出・摄爬 \\
\hline 摘出物の大きさ & $\begin{array}{c}5 \times 3 \mathrm{~cm} \\
21 \mathrm{~g}\end{array}$ & $21 \mathrm{~g}$ & $\begin{array}{c}4 \times 3 \times 3.5 \mathrm{~cm} \\
30 \mathrm{~g}\end{array}$ & $0.5 \times 2 \times 2 \mathrm{~cm}$ & $1.5 \times 1 \times 1 \mathrm{~cm}$ & $\begin{array}{c}7 \times 5 \times 4.5 \mathrm{~cm} \\
60 \mathrm{~g}\end{array}$ \\
\hline 摘出物被膜の有無 & 無 & 無 & 有 & 無 & 1 䊈 & 無 \\
\hline $\mathbf{7}$ & 不 明 & 1 年良好 & 1 年 2 か月良好 & 3 年良好 & 2 年 6 名月良好 & 2 年良好 \\
\hline 発 生 起 & 骨 膜 & $\begin{array}{l}\text { 6! 残根 } \\
\text { 畨周物带 }\end{array}$ & $\begin{array}{l}\text { 上䫑桔節部 } \\
\text { 骨膜 }\end{array}$ & 不 & 不 明 & 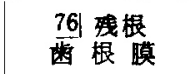 \\
\hline
\end{tabular}

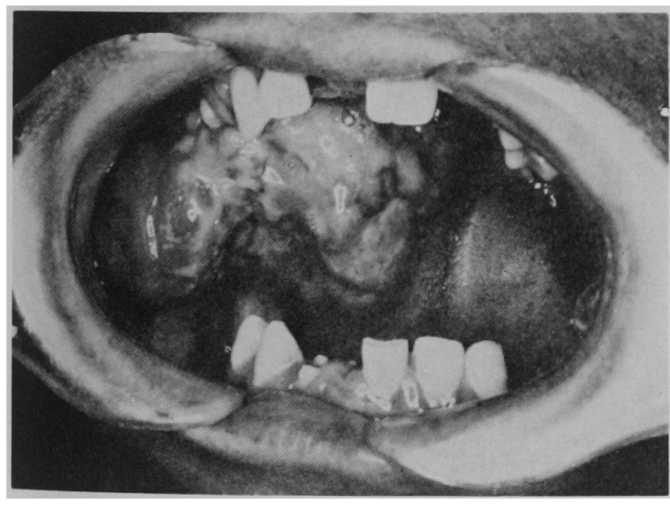

写真 3 初診上り 3 か月後の口腔内所見

月後，腄瘤はさらに急速な増大傾向を示した(写本了).

$\mathbf{X}$ 皛所見：右側上䫑曰歯部より下頻曰歯部歯槽頂部に 近接する䃏篦部に一致して多数の不規則顆粒状の不透過

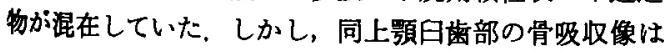

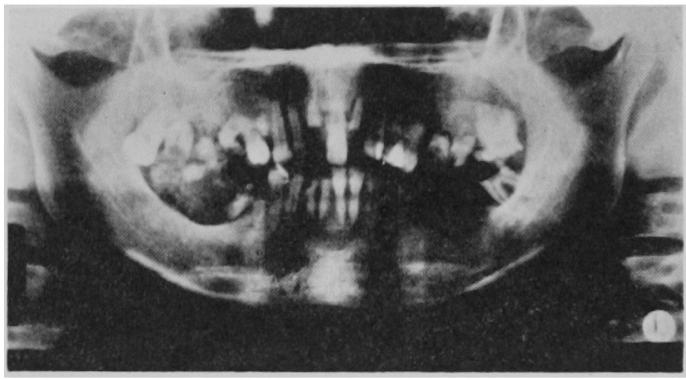

写五 4 初彰時 $\mathrm{X}$ 線所見

明らかではなかった（写真 4，5）.

臨床検查所見：ヘモグロピンが $8.48 / \mathrm{d} l$, ヘマトクリ ットが32.3\%で筫血を示し，HB 抗原は陽性であった。 その他，特に大きな異常所見はみられなかった。

臨床診断：上顆腫瘍.

処置および释過：同年 6 月曰日，GOF 全麻下に腫瘤 摘出手術を行った。㢈瘤の基底部之思われる周囲に切開 


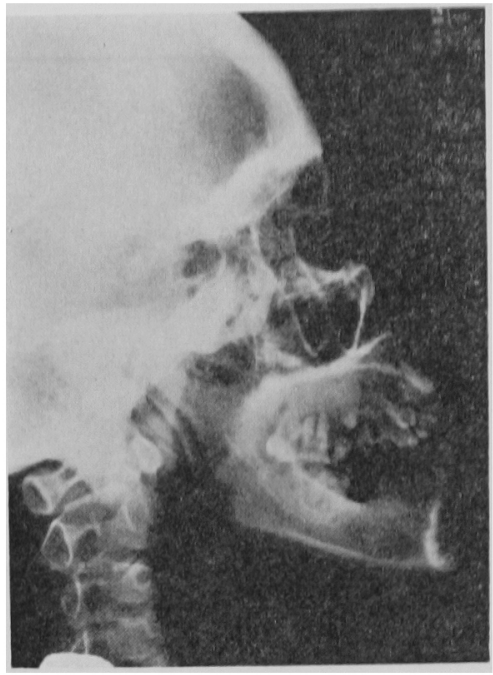

写竞 5 初趁特 X線所見

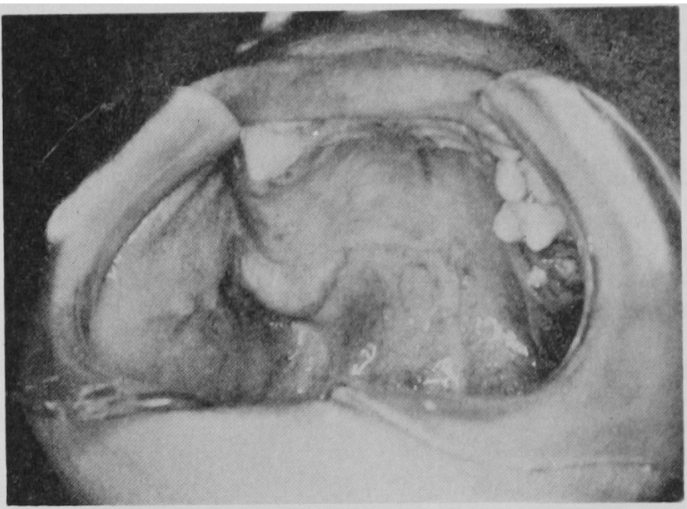

写真 6 手囸後 2 年の口腔内所見

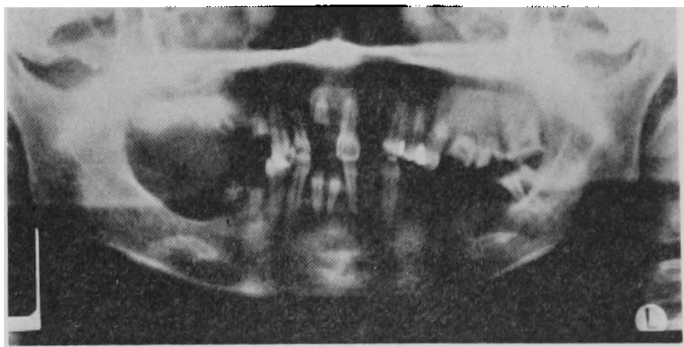

写真 7 手術後 2 年のX線所見

を加え，骨瞙とともに剩離し，一塊として摘出した，尰 瘤の基部は 76 残根部で, 歯槽骨面は凹凸粗造を呈し, 同部を十分削除した．創面を抗生剂軟高塗布ガーゼで覆 い,ついでセルロイド床を装着して手術を終了した。術 後释過は良好で約 2 年を経過した現在，再発等の異常は

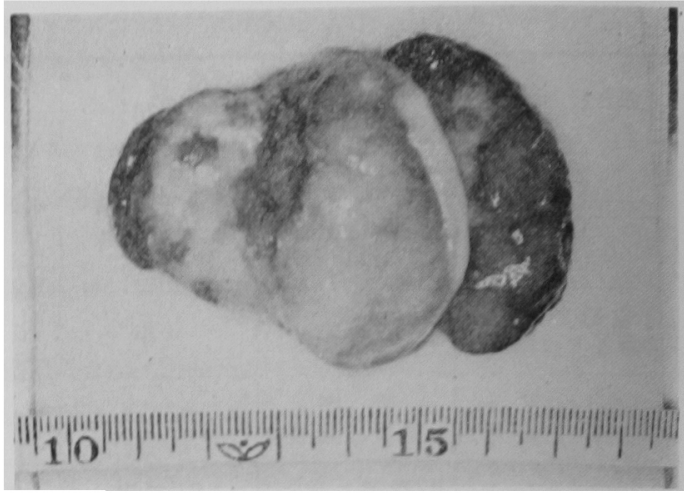

军正8 简出物所見

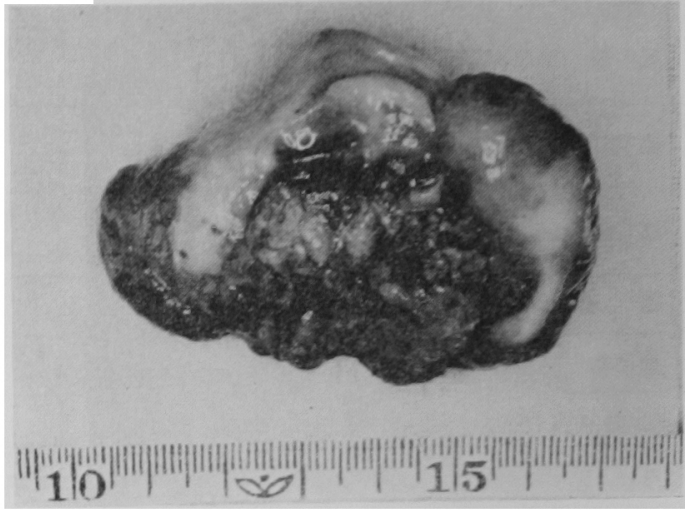

写真 9 摘出物所見

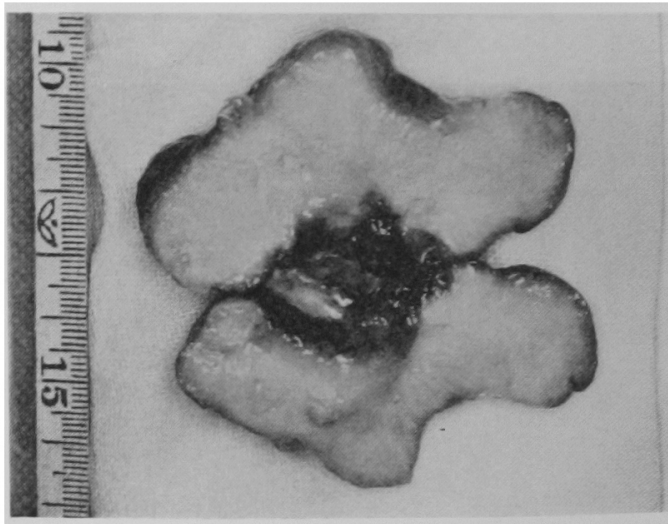

写率 10 摘出物の割面所見

認められていない（写直 6，7）.

摘出物所見: 大きさは7.0×5.0×4.5 cm, 重量は60 であった（写真 8，9）。摘出物の割面は充実性で灭白色 を呈し，多数の石灰化物が認められた（写真10）、X楾 所見では，畽瘤内部に多数のX線不透過物が散在してい 


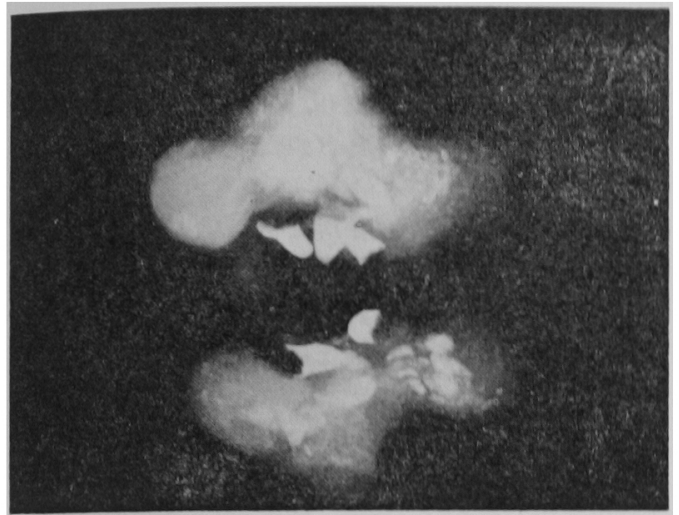

写兵 11 滳出物のX線所見

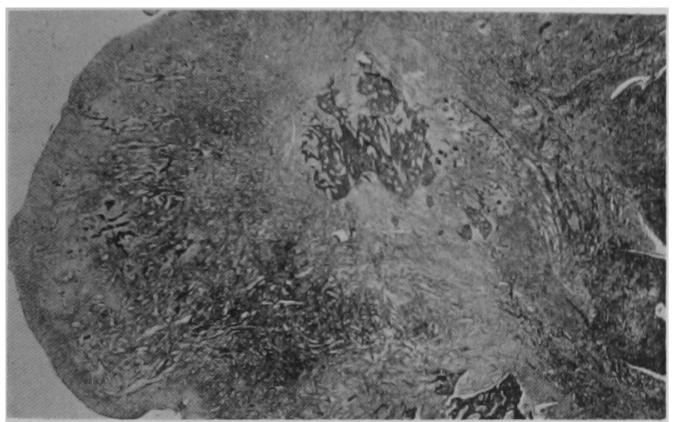

写真 12 摘出物中央部の組織全体像 右端に牫根があり，増殖している線維性組馀内に は硬租織が散在している（H-E，×2.4）

\section{た（写真11）。}

病理組䄳学的所見：尰溜の基底部には残根があり，そ の周囲に画槽骨の一部と思われる骨組織がみられた，腫 瘦は線維性組織の增殖で，そのなかに不規則な形をした 硬組織が散在していた（写真12），增殖している楾維珄 組織は紡鍾形の核を有する賿原線維の束状増殖て，小血 管周囲ではその配列が比較的蹯であった，線維性組織内 の硬組織は円形，楕円形，あるいは不規則な形をした小 塊状，をたは梁状の骨組織で，細胞成分を含を骨小腔を 有していた（写真13）。また，この骨組織 には層板構造 や類骨組織をみるものもあった，增殖している線維性組 織ならびに骨組織に，異型性など覀性を思わせる像はみ られなかった，畽瘤の表面は重層扁平上皮で被覆されて いるが，大部分は上皮が剝離し，線稚素性化膿性炎の像 を呈していた，上皮值下は軽度ないし中等度の慢性炎症 性細胞浸潤を伴った肉芽組織で，この肉芽組織と增殖し ている線維性組織との境界は比較的明瞭であった（写京 14).

診 断：以上の臨床所見， $\mathbf{X}$ 線所見，ならびに病理組

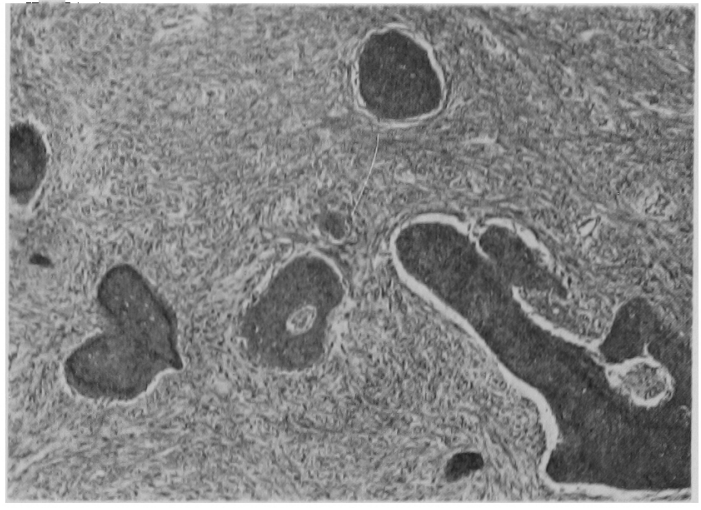

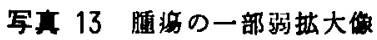

線䧽性組耤の增殖と散在する骨組織 $(\mathrm{H}-\mathrm{E}, \times 40)$

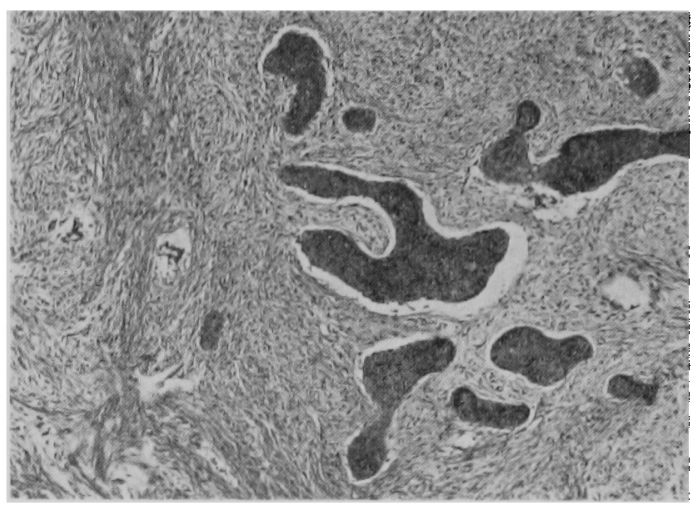

军克 14 睡境の周辺部の㐷拡大作

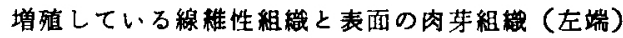
々の境界は比較的明睹である（H-E，×40）

織所見より，周辺性の化骨性線維腫と診断した。

考察

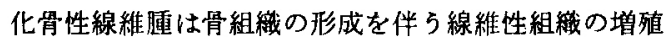
物で，骨線維腫，線維骨腫とも呼ばれ²，その名称は Montogomery ${ }^{2)}$ に始まるといわれる。線維腫には線維 性組織のほかに，骨質などの石灰化成分を含むむのがあ り，線維成分と石灰化成分の割合や程度はいろいろであ る が，Thoma ${ }^{4)}$ はこれを化骨性線維尰，線維類骨骨 腫、線維骨腫に分類している。

化骨性線維腫は䫑骨中心性，あるいは頻骨周辺性に生 ずる比較的まれな腫痬であり，本邦での口腔外科領域に 扮ける報告例は，安藤ららによと74例である。そのう ち周辺性化骨性線維腫はわれわれが涉消したかぎり，大 木 $5^{6)}$, 伊藤 $5^{7}$, 本田 $5^{8)}$, 山崎 $5^{0)}$ (2 例) の 5 例のみ が報告されており，その発生頻度はきわめてまれといえ 
3.

以下，われわれの症例を含めた䧓辺性化惆性線䊒助の 6 例について速べる. 性则では，全症例が女性て，好器

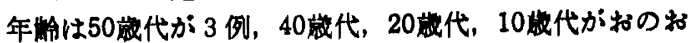

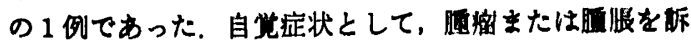

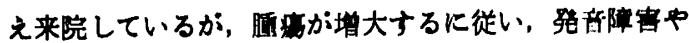
咀喂障害をきたしていた，自觉時期より初釟までの期间 は，報告者により䔬なり，6か月より 5 年の的であった。

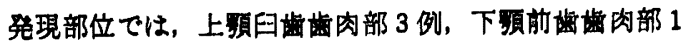

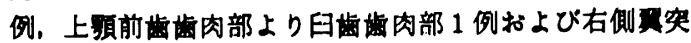

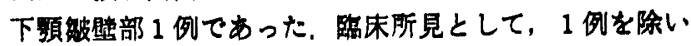

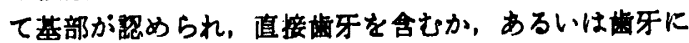

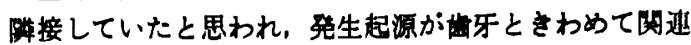
が深いと考えられる．X線所見では，4例において腯癌 相当部に不規則な不逐過物の散在するのを㸾めたが，他 2 例には特に異常所見が琶められなかった，化骨性線 䊒腫は増大，成热するにつれて骨形成革が多くなるとと むに，不透過像が多くなると報告されている1,4,10,11). 䠦床検㚗所見では，特に異常が認められなかった。

額骨は他部位の骨と異なり，その特性として，発生学

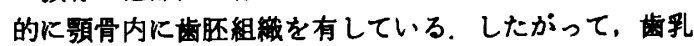

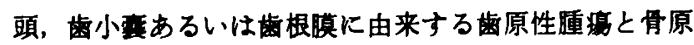
性腫瘍との鑑別が問題となるが，WHO の分類 ${ }^{12)}$ では，

化骨性線䊒庫㤌 Neoplasms and other tumours related to bone の Osteogenic neoplasms のなかに分類されて

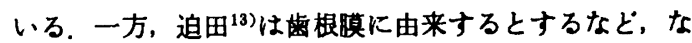
お諸説があるようである。歯根膜はセメント質を歯槽骨 に固着させる線維性組織であるが，また椟槽骨膜にる相 当し，セメント芽細胞とともに骨芽細胞をる分化させ る.つまり線維性組織のなかにセメント質様の硬組織の 形成がみられるセメント質形成線維尰は歯根膜のセメン 卜質形成能を有する細胞に由来し，同様に化骨性線維尰 は崡根膜の骨形成能を有する細胞に由来すると考えられ るとしている ${ }^{13)}$ ，周辺性化骨性線䧽腫の 6 例において, その発生起源墙根膜あるい恃骨瞙とされているが，骨 膜由来とするものも発現部位が粀牙に近接しており，歯 原性由来む否定できないであろう。

化骨性線維腫と fibrous dysplasia との鑑別について, 両疾患の関係はいまだ一致した見解がなく、Jaffeゃ Lichtenstein ${ }^{14)}$, Schlumberger $5^{15)}$ は化骨性線維連を fibrous dysplasia の一型として扱い, Phemister ${ }^{10)}$, Ackerman ${ }^{17)}$ ，Kempson 5 ${ }^{18)}$ は独立した別の疾患とみ ている. 化骨性線維腫と fibrous dysplasia では, 境界 の明瞙度，骨梁の性状，間質の性状に相连がみられる が，特に篮別上重要な点として，fibrous dysplasia には 線維骨から層板骨への移行の障害，すなわら骨梁の成热 過程の異常がみられることをあげている19,20)。しかし骨 病変の二次的変化により, 定型的な組織像を逸脱するこ

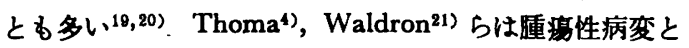

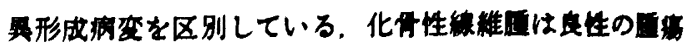
であるが、一为 fibrous dysplasia は末分化な骨形成间

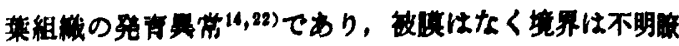
で，一定の大きさ㳀するとついには剒大が传止する特

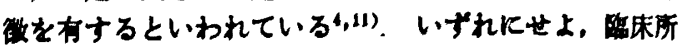

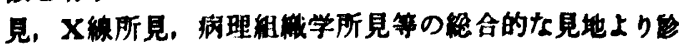
断されているよろである1,21,20,2u．

他方、エフーリスとの䟚であるが、エフーリスとは

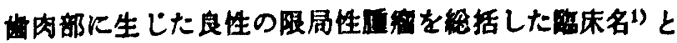

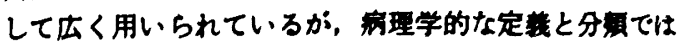
いまなお見解が一致していない、そのおるな成原点恃齿

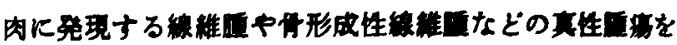

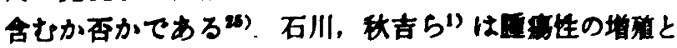

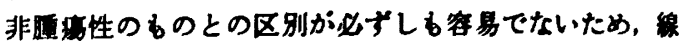

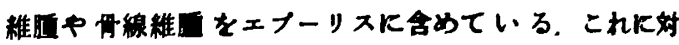

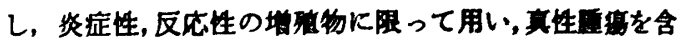

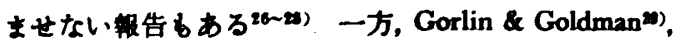
Pindborg ${ }^{30)}$ らは病理喆断名としてェフーリスの名苏を さけ, celluler inflammatory hyperplacia fibrous inflammatory hyperplacia pyogenic granuloma 等の 名称を用いており，石田ら 病理組變学的に別され5るとしてェプーリスから除外 している.

われわれの症例は化骨性線䧴通と診断したか，石川，

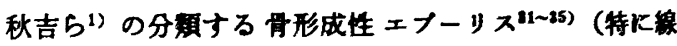
傕骨腫性エプーリス）と称される可能生については，な お検討されねばならない。なお，周讱性化骨性線鹤連と

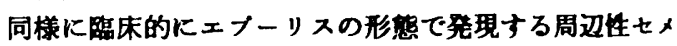

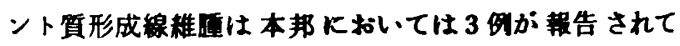
いる ${ }^{36,87)}$.

周辺性化骨性線稚愿飞おりる摘出物の大きさは，本 症例の $60 \mathrm{~g}$ が㵊大であり,ついで $30 \mathrm{~g}, 21 \mathrm{~g}, 21 \mathrm{~g}$ な どとなっていた，原的の增大は必ずしも発育期間と一 致していない，発有は一般に槡侵であるといわれてい る1,4,11)か，われわれの症例は短期間に急速な増大㑯向

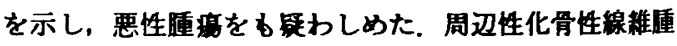
の処置は，摘出および掊出・振煺が行われている. 摘

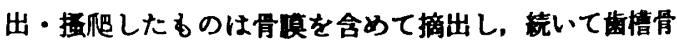

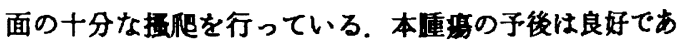

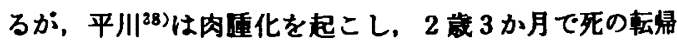
をとった線䊒性骨腫の症例を報告しており，注意深い経 過钼察が必要であると思われる30,40).われわれの症例は 衍後 2 年を経過しているか，再発の徽候は全く認められ ナ゙，現在経過恃良好である。

\section{結語}

われわれは27葴の女性で，右側上䫑曰雪部より口蓋に かけて発生した巨大な周辺性化骨性線雃稙を释検した。 


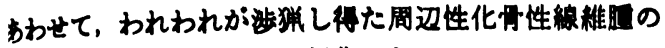
5 例を含め，考察を加えて報告した。

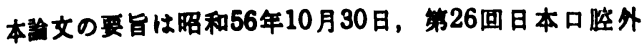
科学会絵会において哞实した。

\section{引用文部}

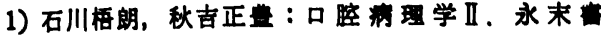
店, 京都, 1969, 969頁.

2) Montogomery, A.H.: Ossifying fibroma of the jaws. Arch Surg 15: 301927.

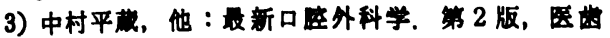
萖出版，東京，1974，679天。

4) Thoma, K.H., Goldman, H.M.: Oral pathology. ed 4, Mosby Co, St Louis, 1954, p 1274.

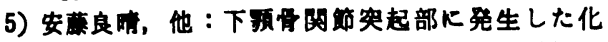

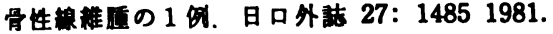

6）大木茂婎，他：骨新生を伴える線雃睡の 1 侧. 界展望 11：49 1954.

7）伊蓝师夫, 他 : Peripheral ossifying fibroma と Pleomorphic adenoma を併発した 1 症例，口 科誌 27: 3141978.

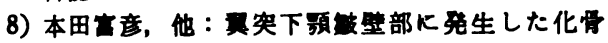

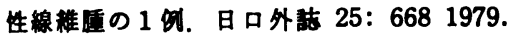

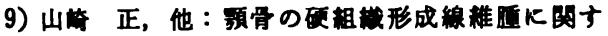
万病理柤栈学的考察. 日外志 28: 10971982.

10) Shafer, W.G., et al.: Textbook of Oral Pathology. ed 3, Saunders Co, Philadelphia, 1974, p 130.

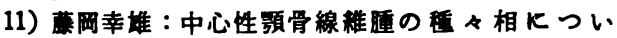
て. 口科誌 9: 3231960.

12) Pindborg, J.J., Krammer, I.R.: Histological Typing of Odontogenic Tumours, Jaw Cysts, and Allied Lesions. WHO Geneva, 1971, p 36.

13）迫田由起子：频骨の Fibro-osseous Lesion. 第

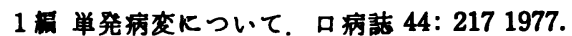

14) Lichtenstein,L. and Jaffe, H.L.: Fibrous dysplasia of bone. Arch path 33: 7771942.

15) Schlumberger, H.G.: Fibrous dysplasia of single bones (Monostotic fibrous dysplasia). Milit Surg 99: 5041946.

16) Phemister, D.B. and Grimson, K.S.: Fibrous osteoma of jaws. Ann Surg 105: 5641937.

17) Ackerman, L.V. and Rosai, J.: Surgical Pathology. Mosby Co, St Louis, 1974.

18) Kempson, R.L.: Ossifying fibroma of the long bone. A light and electron microscopic study. Arch Path 82: 2181966.

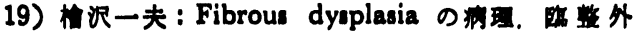
11: 4221976.

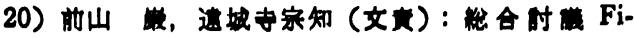
brous dysplasia の卧床と城。些外 11: 4481976.

21) Waldron, C.A.: Fibrous-osseous lesion of the jaws. J Oral Surg 28: 581970.

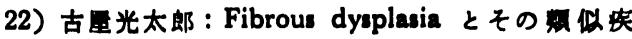

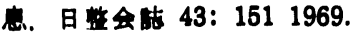

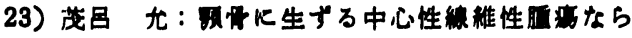

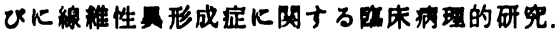
日大部学 41：389 1967.

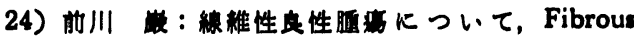

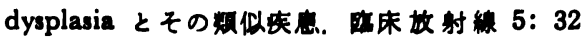
1960.

25）石田 武，他：エプーリスの分類と自治例 160

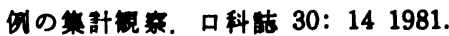

26) Farmer, E.D. and Lawton, F.E.: Stones' Oral and Dental Diseases. Churchill Livingstone, Edinburgh and London, 1966, p 977.

27) Spouge, J.D.: Oral Pathology. Mosby Co, St Louis, 1973, p 225.

28) Bhasker, S.N.: Synopsis of oral pathology. Mosby Co, St Louis, 1970, p 468.

29) Gorlin, R.J. and Goldman, H.M.: Thoma's Oral Pathology Mosby Co, St Louis, 1970, p 861.

30) Pindborg, J.J.: Atlas of Diseases of the Oral Mucosa. Munksgaad, North and South America, 1973, p 166.

31）港川富雄，他：骨形成性エフーーリスの6 例につ いて。西科時報 25: 101971 .

32）成山三郎，他：骨形成を伴なった巨大な線椎性 エプーリスの1例(会). 口科誌 20：8951971.

33）平岡研，他：巨大化した骨形成性エフフーリス の1例 (会). 日口外矿 23：7301977.

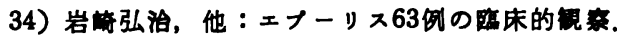
日口外誌 22: 3321976.

35）高木澄雄，他：線雄骨腫性エプーリスの1应例 について。 日外誌 27：1507 1981.

36）梶山稳，他: Cementfying fibroma $の 1$ 侏. 日口外誌 26：166 1980 .

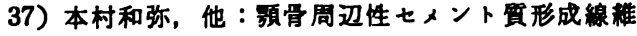
近について。 日外声 28: 8581982.

38）平川正算，他：肉腫化を起こし死の枟㛿をとっ た下预対炤性 Osteofibrom に就いて, 九州齿 会此 6: 111952.

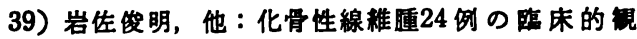
察. 口病誌 47：334 1980.

40）安住知彦, 他: 化骨性線䧴尰の 6 症例. 日外 誌 23: 1581977. 